PECPR:D

HOV 12 is:

OSTI

Radioactive Contamination Incidents

Involving Protective Clothing 
An Affirmative Action/Equal Opportunity Employer

This report was prepared as an account of work sponsored by an agency of the United States Government. Neither The Regents of the University of California, the United States Government nor any agency thereof, nor any of their employees, makes any warranty, express or implied, or assumes any legal liability or responsibility for the accuracy, completeness, or usefulness of any information, apparatus, product, or process disclosed, or represents that its use would not infringe privately owned rights. Reference herein to any specific commercial product, process, or service by trade name, trademark, manufacturer, or otherwise, does not necessarily constitute or imply its endorsement, recommendation, or favoring by The Regents of the University of California, the United States Government, or any agency thereof. The views and opinions of authors expressed herein do not necessarily state or reflect those of The Regents of the University of California, the United States Government, or any agency thereof. The Los Alamos National Laboratory strongly supports academic freedom and a researcher's right to publish; however, the Laboratory as an institution does not endorse the viewpoint of a publication or guarantee its technical correctness. 
Radioactive Contamination Incidents Involving Protective Clothing

Richard Reichelt

Marc Clay

Jeff Eichorst* 


\section{DISCLAIMER}

Portions of this document may be illegible in electronic image products. Images are produced from the best available original document. 


\section{DISCLAIMER}

This report was prepared as an account of work sponsored by an agency of the United States Government. Neither the United States Government nor any agency thereof, nor any of their employees, makes any warranty, express or implied, or assumes any legal liability or responsibility for the accuracy, completeness, or usefulness of any information, apparatus, product, or process disclosed, or represents that its use would not infringe privately owned rights. Reference herein to any specific commercial product, process, or service by trade name, trademark, manufacturer, or otherwise does not necessarily constitute or imply its endorsement, recommendation, or favoring by the United States Government or any agency thereof. The views and opinions of authors expressed herein do not necessarily state or reflect those of the United States Government or any agency thereof. 


\title{
RADIOACTIVE CONTAMINATION INCIDENTS INVOLVING PROTECTIVE CLOTHING
}

by

Richard Reichelt, Marc Clay, and Jeff Eichorst

\begin{abstract}
The study focuses on incidents at Department of Energy (DOE) facilities involving the migration of radioactive contaminants through protective clothing. The authors analyzed 68 occurrence reports for the following factors: (1) type of work; (2) working conditions; (3) type of anti-contamination (anti-C) material; (4) area of body or clothing contaminated; and (5) nature of spread of contamination. A majority of reports identified strenuous work activities such as maintenance, construction, or decontamination and decommissioning (D\&D) projects. The reports also indicated adverse working conditions that included hot and humid or cramped work environments. The type of anti-C clothing most often identified was cotton or waterresistant, disposable clothing. Most of the reports also indicated contaminants migrating through perspiration-soaked areas, typically in the knees and forearms. On the basis of their survey, the authors recommend the use of improved engineering controls and resilient, breathable, waterproof protective clothing for work in hot, humid, or damp areas where the possibility of prolonged contact with contamination cannot be easily avoided or controlled.
\end{abstract}

\section{Introduction}

Protective clothing is often the final safety barrier for workers who handle radioactive materials or work in radioactively contaminated environments. What causes protective clothing to fail? This report examines 68 skin and clothing contamination incidents at Department of Energy (DOE) facilities. In each of the incidents, workers were contaminated when radioactive contaminants penetrated protective clothing. There were a variety of reasons for the penetrations: heavy perspiration, splashes or spills, strenuous working conditions, or prolonged contact with contamination.

\section{Method}

To prepare this report, the authors searched for and analyzed occurrence reports in the Occurrence Reporting and Processing System (ORPS) database. The database contains approximately six years of data on DOE occurrences. The searches focused on reports of skin or personal clothing contamination in which contamination appeared to penetrate radiological protective (anti-C) clothing. 
To find these reports, the authors searched the ORPS database using key words such as leach, damp, permeate, penetrate, wick, damage, tear, and migrate. After an initial selection, the authors discarded reports involving doffing errors or other problems not related to the failure or unsuitability of protective clothing. Further searches used keywords gleaned from the initial selection of reports. Appendix B provides a complete list of the 68 reports.

\section{Characteristic Incident}

A characteristic incident occurred at Los Alamos National Laboratory in 1996.' Maintenance personnel began repairs on a clogged vacuum line for a glovebox that hadn't been used for several years. One employee sat underneath the glovebox and began removing sections of line. After working for about one hour, he noticed a lot of grayish, flaky matter falling from the pipes. The employee rapidly finished the job and exited the space. A radiological control technician subsequently discovered alpha contamination on the employee's left forearm and legs. This incident shares the following features with other incidents throughout the DOE complex:

1. The type of work was maintenance-related. Similar occurrences involve construction, maintenance, and decontamination and decommissioning (D\&D) activities. The occurrence reports usually describe physically demanding work that requires a lot of flexing or kneeling.

2. The employee worked in strenuous conditions. In the characteristic incident, the worker performed the repairs by sitting on the floor under the glovebox and extending his left arm over his head. The vacuum line was located in a tight-fitting 5 -in. space between the glovebox and wall. The employee worked under these strenuous conditions for more than one hour cutting and removing sections of contaminated line. He perspired heavily during this work. Similar occurrences describe employees who must work in cramped spaces or poorly ventilated areas, often near contaminated liquids or surfaces.

3. The employee wore all the required protective clothing. The employee wore a full set of anticontamination (anti-C) clothing that included a Tyvek ${ }^{\odot}$ full-body suit, two pairs of cloth coveralls, four pairs of surgeon gloves, several pairs of cloth booties, a skull cap, and a full-face respirator. All openings in the clothing were taped closed. As with other similar occurrences, the employee wore all the protective clothing required by the radiological work permit (RWP) and specified at the prejob briefing.

4. The contaminated body areas matched stress areas on the clothing. Surveys during the removal of protective clothing revealed contamination on each layer of the employee's anti-C clothing on the left forearm, hip, and calf. These clothing areas were the same body areas exercised for the repair work. Other incidents show a high percentage of contamination events in highly stressed areas. In particular, workers' knees and forearms often become contaminated.

5. A post-incident survey revealed the clothing to be intact. No rips or tears were discovered in the protective clothing. In general, most of the reports describe intact protective clothing, or they describe events that result from contamination penetrating a damaged area in the outer layer of protective clothing and migrating through intact inner layers.

\section{Survey of Similar Reports}

The authors discovered the same five elements repeated in 68 occurrence reports from DOE facilities. This section discusses the elements in the following order: (a) type of work, (b) working conditions, (c) type of anti-C clothing, (d) area of body or clothing contaminated, and (e) nature of spread of contamination. The discussions are illustrated with charts and examples from occurrence reports. 


\section{A. Type of Work}

Figure 1 shows the types of work involved in the protective clothing incidents. Of the selected reports, $36 \%$ identify maintenance work; $28 \%$ identify D\&D work; $24 \%$ identify operational activities; and $12 \%$ identify construction activities. As the categories suggest, most of the work in these incidents involved flexing, lifting, working on hands and knees, or other physical movements.

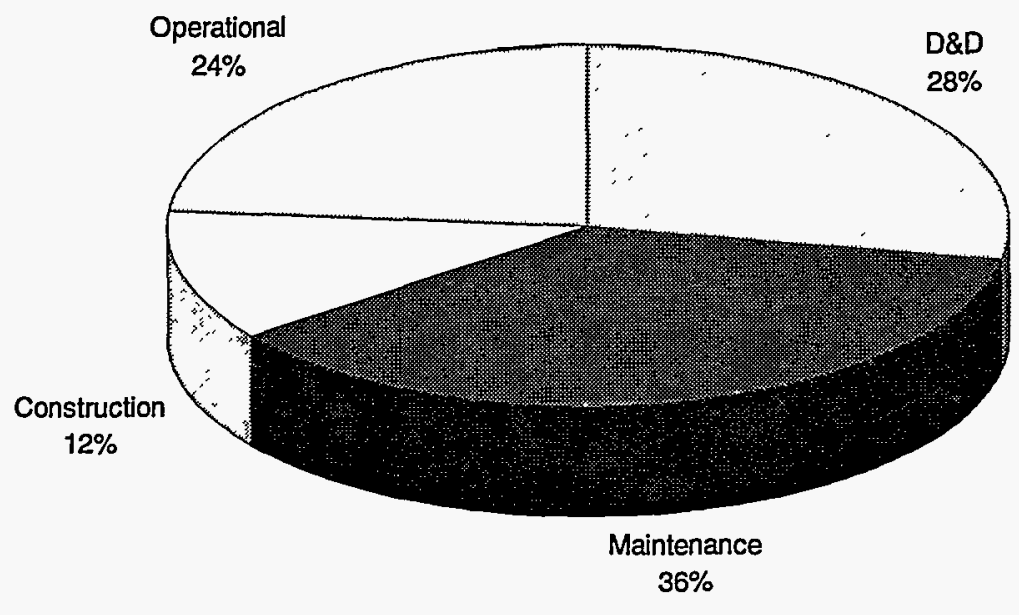

Figure 1: Type of work in protective clothing incidents.

Almost without exception, the reports describe "strenuous" activities or "heavy work." They describe workers operating jackhammers, welding pipes, and scrubbing floors. A 1991 report from the Idaho National Engineering Laboratory describes one worker whose hair was contaminated while he performed carpentry work in a contamination area. ${ }^{2}$ The worker was sawing and nailing lumber to build a scaffold. An investigation revealed he had probably contaminated his cloth hood—dampened with perspiration-by rubbing it with a contaminated glove.

Most reports connect strenuous work with perspiration. A 1994 report from Brookhaven Medical Research Center describes a maintenance worker who replaced a contaminated high-efficiency particulate air (HEPA) filter.

Contamination was later discovered on his knees and elbows. The report states, "The physical exertion required to remove the filters combined with the limited ventilation in the work space caused the worker to perspire and the cotton coveralls to become damp." ${ }^{13}$ As the Brookhaven report suggests, many reports also connect certain types of work with strenuous working conditions. The next section examines those working conditions.

\section{B. Working Conditions}

Figure 2 shows working conditions identified in the occurrence reports. Of the reports that identify a working condition (or one that can be inferred), $84 \%$ identify hot, humid, or damp conditions; $27 \%$ identify confined or cramped spaces; and $18 \%$ identify activities of long duration. Note that some reports identify more than one type of working condition (e.g., working for a long duration in hot conditions).

Most of the reports identify hot, humid, or damp working conditions. A 1992 report from Idaho National Engineering Laboratories describes a typical occurrence. Two personnel were performing D\&D work that involved spraying water and scrubbing a containment around a dolly trench. The personnel sprayed decontamination wash and scrubbed with brushes on their hands and knees. Despite wearing multiple layers of water-resistant protective clothing, both personnel received contamination on their knees. The report states, "With the conditions inside the 
containment being humid, damp, and involving high levels of contamination, further evaluation of proper clothing should have been performed ..."

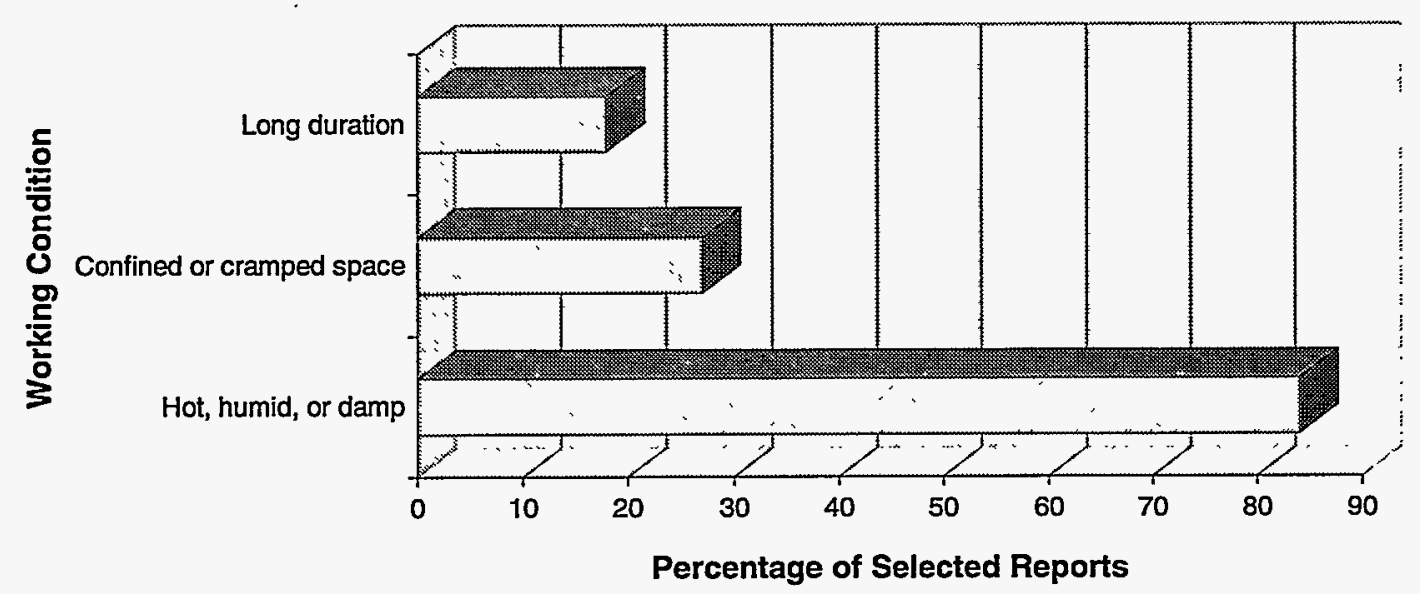

Figure 2: Working conditions in protective clothing incidents.

Other hot, humid, or damp working conditions are due to the weather. A 1993 report from Oak Ridge National Laboratory describes a worker who moved drums in $90^{\circ} \mathrm{F}$ heat..$^{5}$ After the work was complete, contamination was discovered on his left forearm. The heat caused the worker to sweat excessively, soaking his protective clothing and allowing contamination to leach through the fabric.

Other weather-related contamination occurrences involve work in rainy or snowy conditions. A typical occurrence happened at the Los Alamos Neutron Scattering Center in 1996. An employee entered a pump pit to repair a leaking, radioactively contaminated pump assembly. A light rain was falling as he entered the pit. Because the pump shielding had been partially removed (to gain access to the pump), rain also fell into the pit and on the surface where the employee sat to perform repairs. Afterwards, the employee detected contamination on his personal clothing. The probable cause of the incident was that the rain-dampened surface moistened the employee's protective clothing and "allowed contamination to migrate through the suit to the underlying personal clothing."6

Confined or cramped spaces combine different types of working conditions. The spaces are likely to be hot and poorly ventilated. Workers must perform physically awkward or difficult movements, and they are likely to have prolonged contact with contamination. An example combining all of these elements happened at Oak Ridge in 1993. ${ }^{7}$ In this occurrence, a boilermaker replaced a flange inside a pool demineralizer cell. The temperature inside the cell was high. To replace a flange on the cell, the boilermaker had to lie on top of the cell and press his body against the edge of the flange. The combination of high temperature, cramped working conditions, and long duration caused the boilermaker to perspire heavily. Contamination migrated easily from the flange through his damp clothing.

The reports indicate some working conditions make it difficult for a worker to avoid prolonged contact with contamination. For $\mathrm{D} \& \mathrm{D}$ work and operations performed in hot, damp, or poorly ventilated areas or confined spaces, the anti-C clothing is often the only barrier between the worker and contamination. 


\section{Type of Anti-C Clothing}

Figure 3 shows the types of anti-C clothing material identified in the reports. Of the reports that identify a clothing type (or one that can be inferred), $66 \%$ identify cotton or cotton and polyester weaves; $57 \%$ identify disposable and/or water-resistant material such as Tyvek $^{\oplus}$, Saranex $^{\ominus}$, paper, or plastic; and $4 \%$ identify a waterproof, breathable material. Note that many reports identify more than one type of clothing or multiple layers of one type of protective clothing.

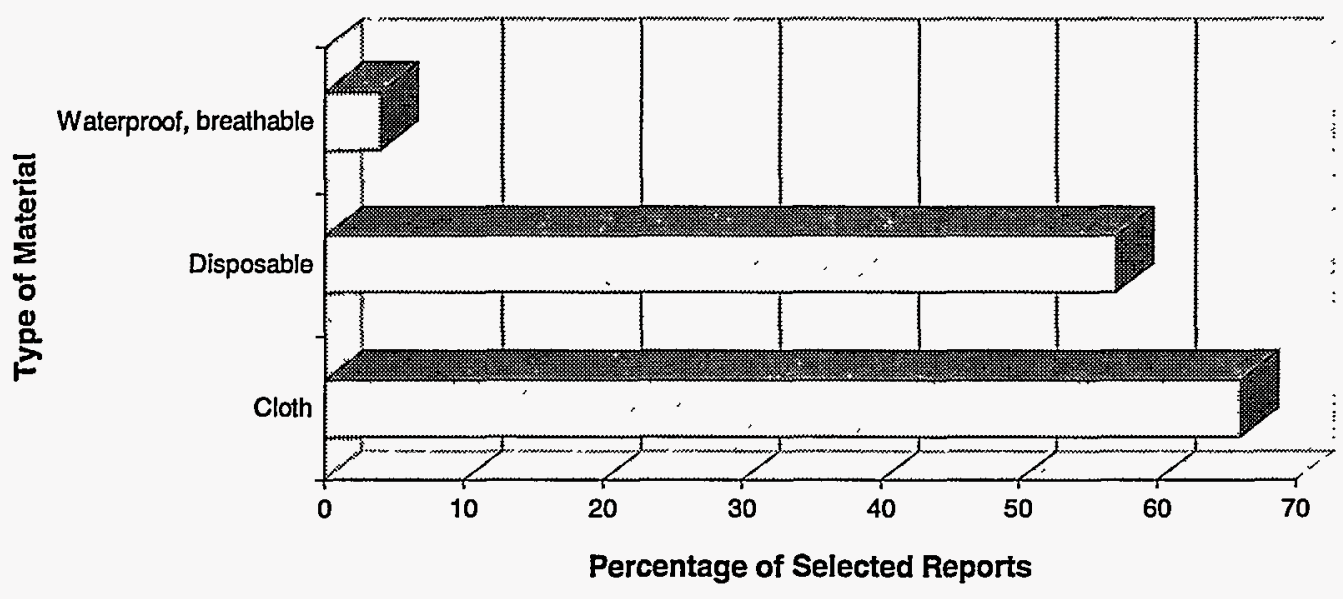

Figure 3: Type of material in protective clothing incidents.

A striking feature of the selected reports is that cloth or water-resistant clothing often fails to protect workers during demanding work conditions or activities. A typical incident took place at the Waste Calcining Facility at the Idaho Chemical Processing Plant in 1995. A worker wore Tyvek ${ }^{\circ}$ and cloth anti-C clothing while performing construction activities and still received beta-gamma contamination on his elbow. The report states, "While the Tyvek being used is adequate for certain applications, it is not the proper PPE for extreme use applications such as construction environments where time, temperature, and severe contact work are not so easily controlled." 8

The chart also shows the low incidence of reports involving waterproof, breathable materials. Only two incidents occurred using this type of material. This low incidence, however, must be compared with the usage of such materials.

Many incidents involve radioactive contaminants leaching through multiple layers of protective clothing. These layers can include combinations of disposable and cloth material. A typical incident happened at Argonne National Laboratory in 1995. Before performing D\&D work, a mechanic donned four sets of anti-C clothing: one inner set of cotton overalls and three outer sets of disposable, water-resistant overalls. He then spent several hours inside a hot cell on his hands and knees removing tape and decontaminating the seams of a false floor. Upon exiting the hot cell, the mechanic discovered contamination on both knees.

The incident report states, "The Radiation Work Permit in effect for the activity being performed failed to adequately address the potential for absorption through multiple layers of protective clothing." suggest that even three or four layers of cotton or disposable, water-resistant protective clothing are inadequate for workers performing strenuous work or working in damp or hot environments.

Multiple layers of protective clothing also exacerbate the problem of heat stress. In an incident at Oak Ridge National Laboratory in 1995, a chemical technician helped to clean up a spill of radioactive liquid. The technician wore a set of personal protective equipment that included a Tyvek ${ }^{\circ}$ suit, cotton coveralls, two pairs of gloves, and a full-face respirator. After only a short time (a health physics technician limited the duration of the activity because 
of heat stress concerns), the worker perspired heavily, lost color, and nearly fainted. When the health physics technician hurriedly doffed the worker's personal protective equipment, the worker's face became contaminated from the exterior of the respirator.

The incident report states, "The scrubbing and scraping was enough physical exertion to cause the [chemical] technician to get very hot under his two layers of protective clothing." 10 This incident illustrates that, for certain activities, multiple layers-particularly when one layer is nonbreathable-cause heat stress problems. Multiple layers are also more likely to make a worker perspire and, consequently, to act as a pathway for contamination.

\section{Area of Body or Clothing Contaminated}

Figure 4 shows the area of the body or clothing contaminated, as described in the reports. Of the selected reports, $43 \%$ identify the legs; $41 \%$ identify the arms; $25 \%$ identify the torso; $13 \%$ identify the head and face; $6 \%$ identify the hands; and $3 \%$ identify the feet.

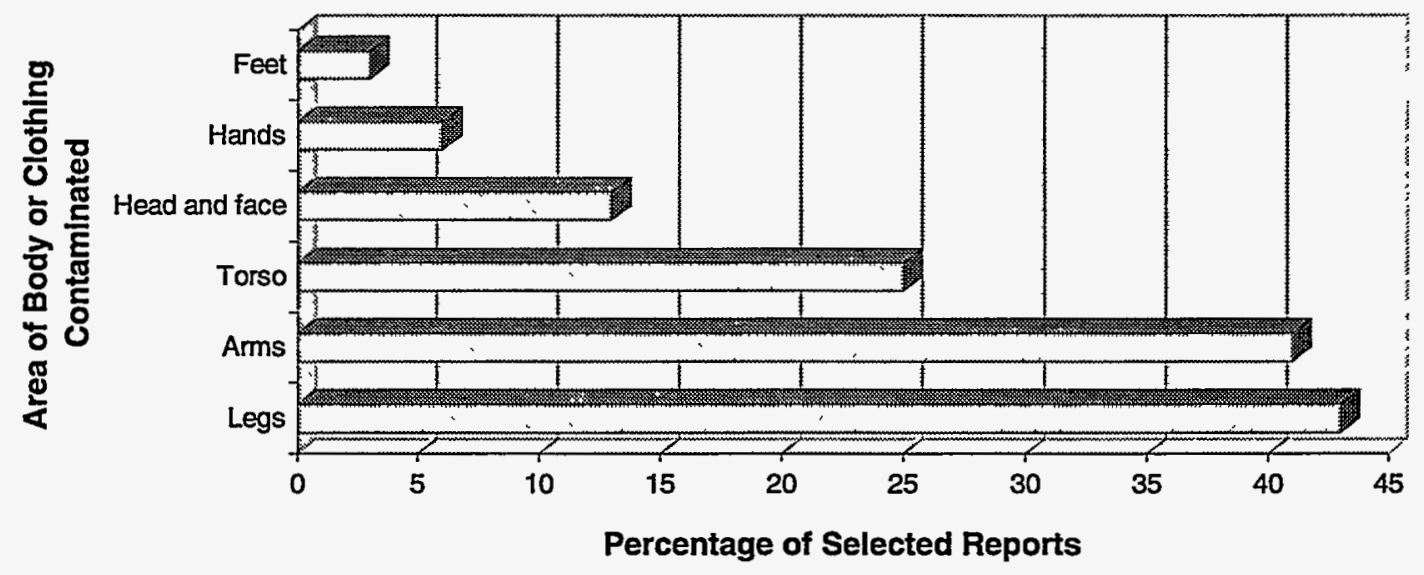

Figure 4: Area of body or clothing contaminated in protective clothing incidents.

The largest category, legs, comprises mostly knee-related incidents. Sixty-eight percent of the reports in this category involve knee contaminations. Numerous incidents involving knee contaminations have already been described. The reason for these incidents appears to be a combination of factors: prolonged contact with contaminated surfaces, physical work that causes perspiration, and high stress placed on the protective clothing.

The second largest category, arms, comprises mostly forearm-related incidents. These reports describe workers using their forearms to enter small spaces, maneuver tools, lean against surfaces, or otherwise come into contact with contamination. An example of a forearm-related incident took place at the Hanford Plutonium Finishing Plant in 1992. An electrician was performing drop light fixture replacements in a glovebox. Alpha contamination was subsequently detected on his right arm. The report states, "The limited work space, combined with the precarious position for manipulating the drop light fixtures through the gloveports, caused the forearm of the electrician to rest/ride on the sharp thread ends of a limit switch mounting bolt."II The threads cut the clothing and provided a pathway for contamination.

The high percentage of knee- and forearm-related incidents suggests that these areas are vulnerable to contamination. Many of the reports the authors surveyed recognize this vulnerability and provide for corrective actions that include rubber-coated sleeves and knees, aprons, and other protective devices. 


\section{E. Nature of Spread of Contamination}

Figure 5 shows the way radioactive contamination migrates through protective clothing, as described in the selected reports. Of the selected reports, $79 \%$ identify perspiration-soaked clothing; $65 \%$ identify prolonged contact with contamination (e.g., kneeling on a contaminated surface); and $12 \%$ identify a rip or hole in the outer layer of protective clothing that introduced contamination to underlying layers of protective clothing.

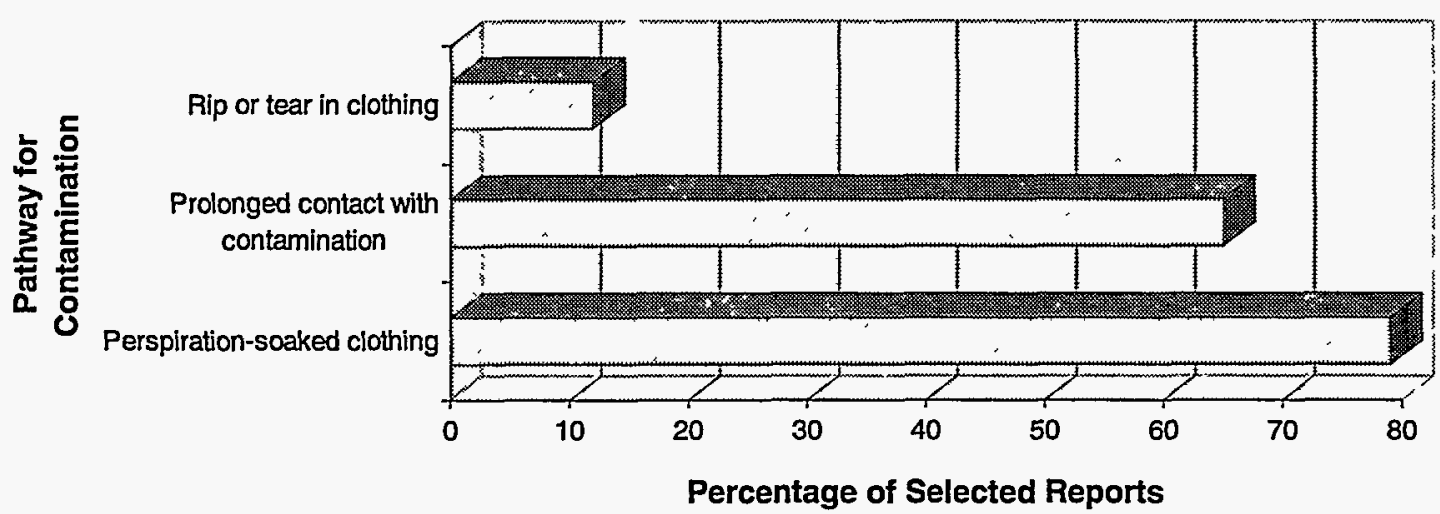

Figure 5: Nature of spread of contamination in protective clothing incidents.

Most reports identify contamination migrating through perspiration-soaked clothing. Frequently, the clothing is surveyed and found to be completely intact, with no holes or tears. A typical example is in the Idaho construction incident previously mentioned. The report states, "The direct cause of this incident was a failure of the personal protective equipment (PPE) to adequately protect the individual. Sweat accumulated on the inside, causing contamination on the outside of the clothing to wick through both the Tyvek and the magenta [cloth] clothing on the exposed employee."8

These reports also describe workers having prolonged contact with contamination-kneeling in liquids, rubbing against surfaces, or handling radioactive materials. A typical incident took place at the Hanford Site in 1992. An operator was bagging out contaminated waste for disposal. The report states, "The bags of waste came into contact with the leg area of the individual while handling them."12 The contamination then migrated through the employee's damp protective clothing. This report shows the overlap between factors. The perspiration-soaked clothing becomes a pathway when it comes into contact with contamination.

\section{v. Survey of Causal Factors}

Figure 6 shows the rank order of causal factors in the selected reports. Of the reports, $64 \%$ identify inadequate planning (or a closely related factor) as the root cause; $20 \%$ identify anti-C clothing failure; and $16 \%$ identify personnel error. Inadequate planning involves a failure to plan for work or provide suitable clothing; anti-C clothing failure describes the failure of the clothing itself; and personnel error describes the failure of workers to change clothing frequently or self-monitor properly. Clearly, a majority of reports concluded these incidents primarily involve a failure of managers to plan for the work or provide adequate protective clothing for their workers. 


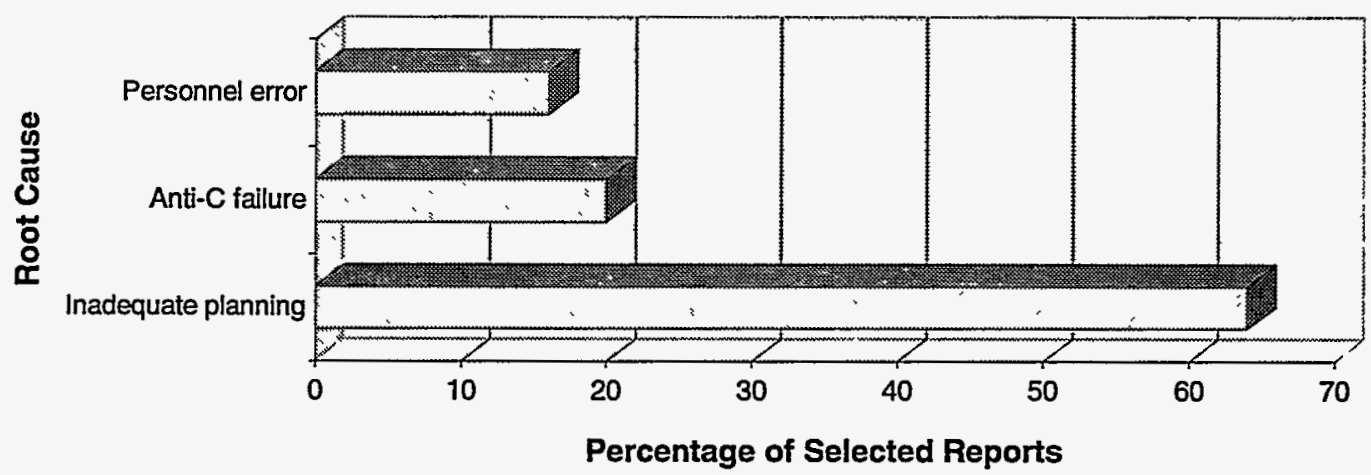

Figure 6: Distribution of root causes in protective clothing incidents.

\section{Survey of Corrective Actions}

The corrective actions identified in these reports can be grouped into five general categories: (1) require more layers of protective clothing to be worn, (2) require more frequent self-monitoring and changeout of protective clothing, (3) perform more effective hazard analysis, (4) implement better engineering controls, and (5) use a more effective protective clothing material. The following is an evaluation of these different types of corrective actions.

1. Require more layers of protective clothing. This is probably the least effective corrective action. As this report shows, contamination quickly leaches through multiple layers of damp cloth or disposable clothing. In addition, multiple layers create problems of heat stress and excessive perspiration and increase the potential for a contamination incident involving a doffing error. Therefore, for strenuous work, requiring additional layers (of disposable or cloth protective clothing) can be ineffective.

2. Require more frequent self-monitoring and changeout of protective clothing. This corrective action is often impractical for strenuous work. The sweating inside some protective clothing (e.g., plastic suits) begins almost from the time the work is first begun. Perspiration is an unavoidable consequence of scrubbing floors, operating jackhammers, and handling heavy equipment. In addition, the frequent changeout of protective clothing increases the likelihood of contamination by doffing errors. Therefore, for strenuous work, requiring workers to perform more frequent self-monitoring and changeout of protective clothing is probably ineffective.

3. Perform more effective hazard analysis and prejob planning. This corrective action is effective as long as it is followed by suitable preventive actions. Plans to spread plastic over contamination, decontaminate areas, or limit employee exposure time can be effective. These types of corrective actions, however, depend on the ability to accurately anticipate hazards in prejob planning and to eliminate employee exposure and contact times.

4. Implement better engineering controls. Shields and barriers (e.g., plastic sheets placed over contaminated areas) or extension tools (e.g., brushes with long handles) are effective in preventing workers from becoming contaminated in certain situations. However, in highly contaminated work environments, these types of protection may need to be supplemented by a more effective type of anti- $\mathrm{C}$ material.

5. Use a more effective anti-C material. A breathable, waterproof protective clothing material is probably the best corrective action for the occurrences described in this report. Such a material would protect the worker and have the added benefit of helping to prevent heat stress. Also, by requiring workers to wear fewer layers of anti-C clothing, the potential for personal contamination resulting from a doffing error is minimized. 


\section{Conclusions and Recommendations}

This report illustrates how contamination can penetrate protective clothing. Some workers may perceive anti-C clothing to be an impermeable shield or barrier protecting against radioactive contamination. However, this perception is not true. Protective clothing, when improperly used, can easily lead to a skin contamination incident.

Some reports in this survey assert that anti-C clothing only protects against "incidental contact." However, for some types of work-D\&D, maintenance, and construction-it is difficult or impossible to ensure that all contact is incidental. If a worker must scrub a floor on his hands and knees, straddle contaminated equipment, or handle contaminated filters, then planners should consider better engineered controls and more effective anti-C clothing. As this report shows, a worker who is wearing perspiration-soaked overalls and brushes a contaminated surface may easily become contaminated.

Perhaps these incidents show the value of "less is more." Multiple layers of cotton and disposable water-resistant protective clothing may only increase the likelihood of a skin contamination incident. Engineering controls and protective clothing that includes waterproof, breathable materials may be an effective option for managers who must balance cost, heat stress, and contamination factors. Appendix A provides a partial list of protective clothing types and compares their characteristics.

Finally, the authors believe that the guidance in Laboratory Standard LS107-09.0, "Radiological Protective Clothing," for Los Alamos National Laboratory should be modified to reflect the operational experience detailed in this report. ${ }^{13}$

\section{References}

1. "Radioactive Contamination Detected on the Skin and Clothing of a JCI Employee after Working in Wing 5, Room 5125, of CMR," Los Alamos National Laboratory, Occurrence Report ALO-LA-LANL-CMR-1996-0012 (1996).

2. "Personnel Skin Contamination," Idaho National Engineering Laboratory, Occurrence Report ID--EGG-ATR1991-1015 (1991).

3. "Personnel Contamination," Brookhaven Medical Research Center, Occurrence Report CH-BH-BNL-BMRR1994-0003 (1994).

4. "Personnel Skin Contamination," Idaho National Engineering Laboratory, Occurrence Report ID--EGGERATRA-1992-0007 (1992).

5. "Contamination Discovered on Left Elbow of Subcontractor Employee from Work Activities in Building 201," Oak Ridge National Laboratory, Occurrence Report ORO--MK-WSSRAP-1993-0036 (1993).

6. "Radioactive Contamination Detected on the Personal Clothing of an AOT-2 Employee After Working in the XO2 Pump Pit at TA-53," Los Alamos National Laboratory, Occurrence Report ALO-LA-LANL ACCCOMPLEX-1996-0013 (1996):

7. "Contamination of Company-Issued Clothing," Oak Ridge National Laboratory, Occurrence Report ORO-MMES-X10HFIR-1993-0020 (1993).

8. "Construction Worker Skin Contamination at CPP-659," Idaho Chemical Processing Plant, Occurrence Report ID--LITC-WASTEMNGT-1995-0016 (1995).

9. "Personnel Contamination," Argonne National Laboratory, Occurrence Report CH-AA-ANLE-ANLEER-19950010 (1995). 
10. "Skin Contamination during Decontamination Work," Oak Ridge National Laboratory, Occurrence Report ORO--MMES-X10REDC-1995-0009 (1995).

11. "Skin Contamination to Electrician's Forearm during Maintenance Activities in Room 235-B," Hanford Plutonium Finishing Plant, Occurrence Report RL--WHC-PFP-1992-0017 (1992).

12. "Personnel Skin Contamination," Hanford Site, Westinghouse Hanford Company, Occurrence Report RL-WHC-PUREX-1992-0107 (1992).

13. “Radiological Protective Clothing," Los Alamos National Laboratory Standard LS107-09.0, (1996).

\section{Acknowledgments}

The authors wish to thank the following companies for providing information for this report:

FRHAM Safety Products, Inc.

318 Hill Ave.

Nashville, TN 37224

(615) 254-0841

Complete Safety Wear 722 E. Osborn Rd.

Suite 400

Phoenix, AZ 85014

(800) $991-9290$

Kimberly-Clark Corporation 1400 Holcomb Bridge Rd.

Roswell, GA 30076

(770) $587-8006$

Interstate-Nuclear Services

295 Parker St.

P.O. Box 51957

Springfield, MA 01151

(413) 543-6911 


\section{Appendix A: Comparison of Protective Clothing Types}


A-2 


\section{Appendix A: Comparison of Protective Clothing Types}

Appendix A compares different types of protective clothing. The table lists only a fraction of the manufacturers of protective clothing. However, it may be used as a guide for evaluating some of the characteristics of protective clothing. The first three columns provide information on the garment type, style, and fabric. The other columns are described below.

1. Porosity. Porosity (fourth column) shows the relative pore sizes of the fabric. The greater the pore size, the more likely it is that contaminants or liquids will pass through the material.

2. Air flow. Air flow (fifth column) indicates the breathability of the fabric. In general, the higher the air flow, the more breathable the material is and the more comfortable it is for a worker to wear.

3. Water vapor breathability. Water vapor breathability (sixth column) indicates the ability of water vapor to pass through the fabric. Among other things, these numbers indicate how well perspiration may be removed from the body. The higher the number, the more a worker's perspiration will be likely to pass through the fabric. Together, the air flow and the water vapor breathability determine the breathability and comfort of a given fabric.

4. Liquid barrier test. Liquid barrier test (seventh column) shows the height of a water column necessary for water droplets to penetrate the protective clothing material. A higher number indicates a more water-resistant garment.

\section{Purchase cost per unit. Self-explanatory.}

6. Seams. Seams (ninth column) provides data on serged, bounded, taped, and welded seams. A serged seam is a stitched seam that interlocks; it is not liquid tight. A bound seam is a stitched seam that is reinforced with an overlay for additional strength; it has excellent tear resistance and is more liquid tight than a serged seam. A welded seam is made by sealing a seam with heat activated tape. This is a liquid tight seam.

7. Closures. Closures (tenth column) provides data on zippers, snaps, drawstrings, and velcro closures.

8. Expected Life. Self-explanatory.

9. Expected Launderings. Self-explanatory.

10. Lease Available. Self-explanatory.

The table shows the characteristics of protective clothing. When determining the suitability of protective clothing, managers should also consider the following: (1) waste disposal costs, (2) laundering costs, (3) warehousing costs, (4) internal storage taxes, (5) the cost of disposable clothing versus the cost of fewer sets of nondisposable clothing, and (6) the cost of nondisposable clothing versus the cost of laundering. These and other associated costs should be considered to determine the true cost-effectiveness of protective clothing. 
Table A: Comparison of Protective Clothing Types

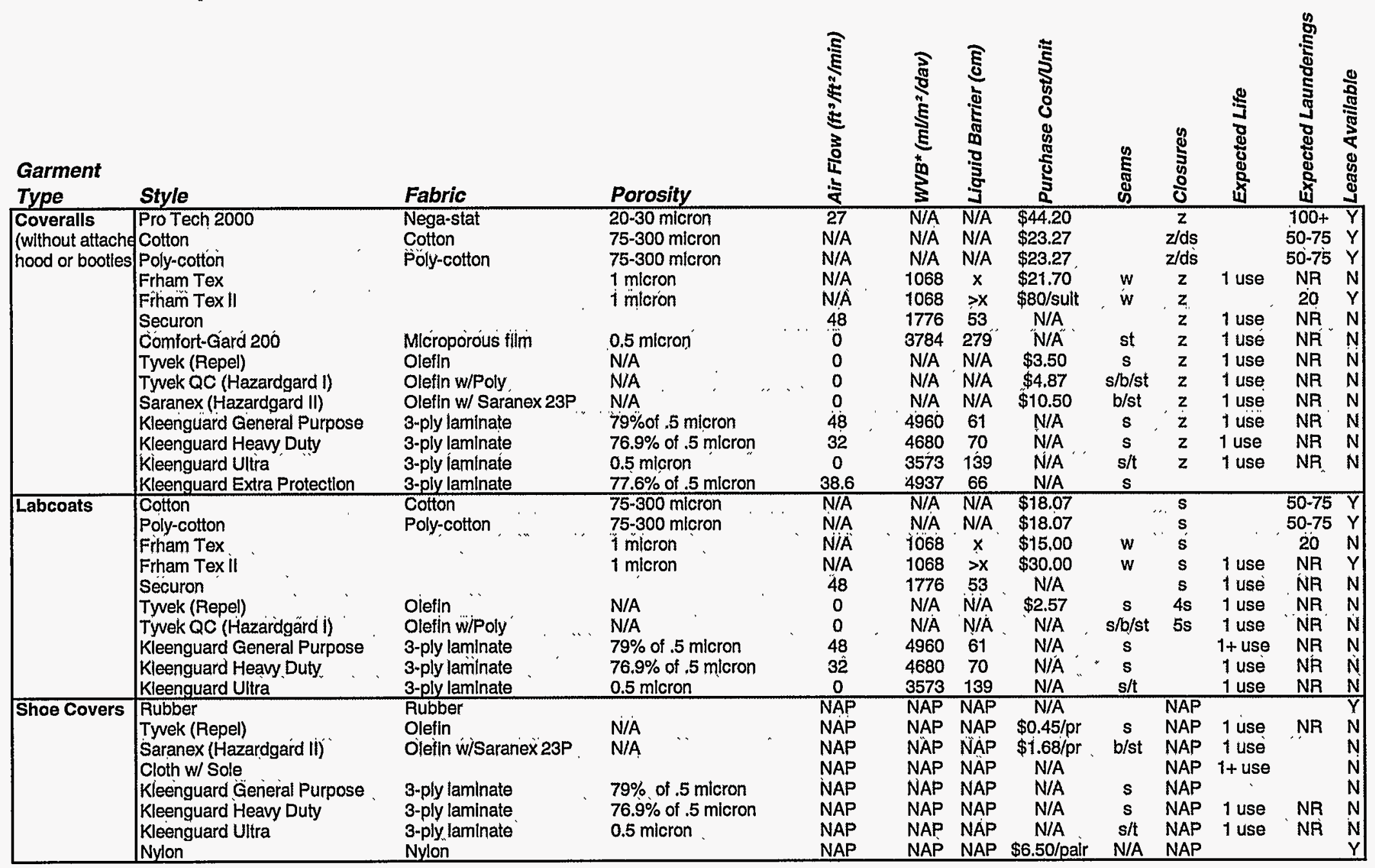


Table A: Comparison of Protective Clothing Types (cont.)

\begin{tabular}{|c|c|c|c|c|c|c|c|c|c|c|c|}
\hline $\begin{array}{c}\text { Garment } \\
\text { Type }\end{array}$ & Style & Fabric & Porosity & 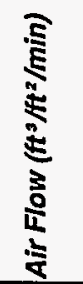 & 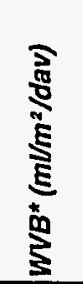 & 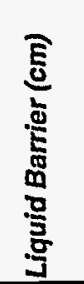 & 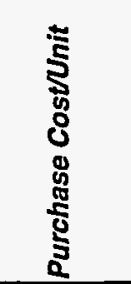 & $\begin{array}{l}\text { ڤ్ } \\
\text { हूँ } \\
\text { ळ }\end{array}$ & 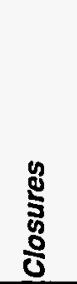 & 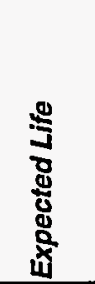 & 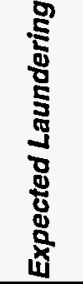 \\
\hline Booties & $\begin{array}{l}\text { Nylon } \\
\text { Frham Tex } \\
\text { Tyvek (Repel) } \\
\text { Saranex (Hazardgard II) } \\
\text { Cotton } \\
\text { Kieenguard General Purpose } \\
\text { Kleenguard Heavy Duty } \\
\text { Kleenguard Ultra } \\
\text { PVC } \\
\text { Urethane-coated Nylon }\end{array}$ & $\begin{array}{l}\text { Nylon } \\
\text { Olefin } \\
\text { Olefin w/ Saranex 23P. } \\
\text { Cotton } \\
\text { 3-ply laminate } \\
\text { 3-ply laminate } \\
\text { 3-ply laminate } \\
\text { PVC } \\
\text { Nylon }\end{array}$ & $\begin{array}{l}\text { N/A } \\
1 \text { micron } \\
\text { N/A } \\
\text { N/A } \\
75-300 \text { micron } \\
79 \% \text { of } .5 \text { micron } \\
76.9 \% \text { of } .5 \text { mlcron } \\
.5 \text { micron }\end{array}$ & $\begin{array}{l}\text { NAP } \\
\text { NAP } \\
\text { NAP } \\
\text { NAP } \\
\text { NAP } \\
\text { NAP } \\
\text { NAP } \\
\text { NAP } \\
\text { NAP } \\
\text { NAP }\end{array}$ & $\begin{array}{l}\text { NAP } \\
\text { NAP } \\
\text { NAP } \\
\text { NAP } \\
\text { NAP } \\
\text { NAP } \\
\text { NAP } \\
\text { NAP } \\
\text { NAP } \\
\text { NAP }\end{array}$ & $\begin{array}{l}\text { NAP } \\
\text { NAP } \\
\text { NAP } \\
\text { NAP } \\
\text { NAP } \\
\text { NAP } \\
\text { NAP } \\
\text { NAP } \\
\text { NAP } \\
\text { NAP }\end{array}$ & $\begin{array}{l}\$ 6.55 / \mathrm{pr} \\
\$ 3.40 / \mathrm{pr} \\
\$ 0.77 / \mathrm{pr} \\
\$ 2.01 / \mathrm{pr} \\
\text { N/A } \\
\text { N/A } \\
\text { N/A } \\
\text { N/A } \\
\text { N/A } \\
\text { N/A }\end{array}$ & $\begin{array}{c}w \\
s \\
b / s t \\
s \\
s \\
s / t\end{array}$ & $\begin{array}{l}\text { NAP } \\
\text { NAP } \\
\text { NAP } \\
\text { NAP } \\
\text { NAP } \\
\text { NAP } \\
\text { NAP } \\
\text { NAP } \\
\text { NAP } \\
\text { NAP }\end{array}$ & $\begin{array}{l}1 \text { use } \\
1 \text { use } \\
1 \text { use } \\
1 \text { use } \\
1 \text { use } \\
1 \text { use }\end{array}$ & $\begin{array}{c}100+ \\
\text { NR } \\
\text { NR } \\
\\
50-7 \overline{5} \\
\text { NR } \\
\text { NR } \\
\text { NR }\end{array}$ \\
\hline Hoods & $\begin{array}{l}\text { ProTech } 2000 \\
\text { Frham Tex } \\
\text { Frham Tex II } \\
\text { Tyvek (Repel) } \\
\text { Kleenguard General Purpose } \\
\text { Kleenguard Heavy Duty } \\
\text { Kleenguard Ultra }\end{array}$ & $\begin{array}{l}\text { Nega-stat } \\
\text { Olefin } \\
\text { 3-ply laminate } \\
\text { 3-ply laminate } \\
\text { 3-ply laminate } \\
\end{array}$ & $\begin{array}{l}20-30 \text { micron } \\
1 \text { micron } \\
1 \text { micron } \\
\text { N/A } \\
79 \% \text { of .5 micron } \\
76.9 \% \text { of } .5 \text { mlcron } \\
0.5 \text { micron } \\
\end{array}$ & $\begin{array}{c}27 \\
N / A \\
N / A \\
0 \\
48 \\
32 \\
0 \\
\end{array}$ & $\begin{array}{l}\text { N/A } \\
1068 \\
1068 \\
N / A \\
4960 \\
4680 \\
3573 \\
\end{array}$ & $\begin{array}{c}\text { N/A } \\
\text { N/A } \\
N / A \\
N / A \\
61 \\
70 \\
139 \\
\end{array}$ & $\begin{array}{c}\$ 13.50 \\
\$ 6.50 \\
\$ 16.00 \\
\$ 0.37\end{array}$ & $\begin{array}{l}w \\
w \\
s \\
s \\
s \\
s / t\end{array}$ & $\begin{array}{c}v \\
v \\
d s\end{array}$ & $\begin{array}{l}1 \text { use } \\
1 \text { use } \\
1 \text { use } \\
1 \text { use } \\
1 \text { use }\end{array}$ & $\begin{array}{l}100+ \\
20 \\
N R \\
N R \\
N R \\
\text { NR } \\
\text { NR }\end{array}$ \\
\hline
\end{tabular}

\section{Key}

\begin{tabular}{|lll|}
\hline Seams & Closures & Other \\
\hline $\mathrm{s}=$ serged & $\mathrm{z}=$ zipper & *WVB = water vapor breathability \\
$\mathrm{b}=$ bound & \#s = number of snaps & $\mathrm{N} / \mathrm{A}=$ not available \\
$\mathrm{t}=$ taped & $\mathrm{d}=$ drawstrings & NAP = not applicable \\
$\mathrm{w}=$ welded & $\mathrm{v}=$ velcro & NR $=$ not recommended \\
\hline
\end{tabular}




\section{List of Manufacturers}

The following is a list of manufacturers of products listed in Table A.

Protech $2000^{\circledR}$

FRHAM Tex ${ }^{\circledR}$ FRHAM Tex $\|^{\circledast}$

Securon $^{\circledast}$

Comfort-Gard $200^{\circledR}$

Tyvek (Repel) ${ }^{\oplus}$

Tyvek QC (Hazardgard I) ${ }^{\circledR}$

Saranex (Hazardgard II) ${ }^{\circledR}$

Kleenguard General

Purpose ${ }^{\circledast}$

Kleenguard Heavy Duty ${ }^{\circledR}$

Kleenguard Ultra ${ }^{\circledR}$

Kleenguard Extra Protection ${ }^{\circledR}$

Cotton

Poly-cotton

PVC

Urethane-coated nylon

Rubber

Cloth w/sole

Nylon
Interstate Nuclear Services

295 Parker St., P.O. Box 51957

Springfield, MA 01151

FRHAM Safety Products, Inc.

318 Hill Ave., P.O. Box 101177

Nashville, TN 37224

Kimberly-Clark Corporation 1400 Holcomb Bridge Road

Roswell, GA 30076
Generic product

Generic product

Generic product

Generic product

Generic product

Generic product

Generic product 
Appendix B: List of Selected Occurrence Reports 
B-2 


\section{Appendix B: List of Selected Occurrence Reports}

The following is a list of the 68 occurrence reports (by occurrence report number) referred to in this report:

1. ALO-KO-SNL-6000REACT-1995-0005

2. ALO-LA-LANL-ACCCOMPLEX-1992-0011

3. ALO-LA-LANL-ACCCOMPLEX-1995-0014

4. ALO-LA-LANL-ACCCOMPLEX-1996-0013

5. ALO-LA-LANL-CMR-1992-0026

6. ALO-LA-LANL-CMR-1996-0010

7. ALO-LA-LANL-CMR-1996-0012

8. ALO-LA-LANL-TA55-1991-1019

9. ALO-LA-LANL-TA55-1991-1021

10. ALO-LA-LANL-TA55-1992-0011

11. CH-AA-ANLE-ANLEER-1994-0013

12. CH-AA-ANLE-ANLEER-1995-0010

13. CH-BH-BNL-BMRR-1994-0003

14. ID--EGG-ATR-1991-1015

15. ID--EGG-ERATRA-1992-0007

16. ID--LITC-ATR-1994-0001

17. ID--LITC-ATR-1995-0006

18. ID--LITC-WASTEMNGT-1995-0004

19. ID--LITC-WASTEMNGT-1995-0016

20. ID--LITC-WERF-1994-0001

21. ID--WINC-ICPP-1991-0054

22. ID--WINC-ICPP-1993-0017

23. ID--WINC-WASTEMNGT-1994-0007

24. NVOO--REEC-EHDO-1990-0016

25. OH-FN-FERM-FEMP-1995-0012

26. OH-FN-FERM-FEMP-1995-0102

27. ORO--FERM-FEMP-1993-0025

28. ORO--FERM-FEMP-1993-0039

29. ORO--FERM-FEMP-1993-0041

30. ORO--FERM-FEMP-1993-0061

31. ORO--FERM-FEMP-1994-0044

32. ORO--MK-WSSRAP-1993-0028

33. ORO--MK-WSSRAP-1993-0033

34. ORO--MK-WSSRAP-1993-0034

35. ORO--MK-WSSRAP-1993-0036

36. ORO--MK-WSSRAP-1994-0020

37. ORO--MKFO-X10CONSTRM-1992-0021

38. ORO--MMES-K25GENLAN-1992-0068

39. ORO--MMES-K25GENLAN-1992-0074

40. ORO--MMES-PGDPFABMNT-1991-1004

41. ORO--MMES-PGDPFABMNT-1991-1005

42. ORO--MMES-PGDPFABMNT-1991-1010

43. ORO--MMES-X10ENVRES-1995-0011

44. ORO--MMES-X10HFIR-1993-0020

45. ORO--MMES-X10METCER-1991-1004

46. ORO--MMES-X10REDC-1995-0009

47. ORO--MMES-Y12DEFPGM-1993-0041

48. ORO--MMES-Y12DEFPGM-1994-0001

49. ORO--WMCO-FEMP-1992-0082

50. RL--BHI-DND-1995-0006
51. RL-PNNL-PNNLNUCL-1991-0084

52. RL--WHC-BPLANT-1990-0177

53. RL--WHC-BPLANT-1991-1032

54. RL--WHC-BPLANT-1991-1034

55. RL-WHC-KBASINS-1994-0034

56. RL--WHC-KBASINS-1995-0005

57. RL--WHC-PFP-1992-0017

58. RL-WHC-PFP-1995-0020

59. RL-WHC-PUREX-1990-0017

60. RL--WHC-PUREX-1992-0107

61. RL--WHC-TPLANT-1992-0027

62. RL-WHC-WHC100ERD-1990-0081

63. SAN--RI-RIHL-1993-0002

64. SR--WSRC-FCAN-1991-0025

65. SR--WSRC-FCAN-1994-0053

66. SR--WSRC-HCAN-1991-1057

67. SR--WSRC-HTANK-1991-1020

68. SR--WSRC-HTANK-1995-0068 
B-4 
• 
